\title{
TWO NEW TINGITIDS (HEMIPTERA) FROM
}

\section{PANAMA}

\author{
By Carl J. Drake \\ Ames, Iowa
}

The present paper contains the description of two new species of lace-bugs collected in the Canal Zone, Panama, by the author. The types are in the Drake Collection.

\section{Gargaphia paula sp. nov.}

Moderately short, broad, testaceous, the elytra with an oblique fuscous band near the apex. Head black, with five, pale, testaceous spines, the median and hind pair longer. Antennæ slender, moderately long; segments I and II black, the former stouter and three times as long as the latter; III long, testaceous, two and one-half times as long as IV; IV long, the distal three-fourths black. Pronotum black, the triangular portion testaceous. Carinæ foliaceous, testaceous, uniseriate; lateral carinæ not quite extending as far forward as the base of the hood, slightly converging behind; median carina slightly more elevated. Hood moderately large, roof-shaped above, highest in front, projecting slightly forward in front. Paranota moderately broad, testaceous, biseriate, the outer margin rounded.

Rostrum extending to the interrupted channel. Elytra very similar in appearance and markings to $L$. lineata (Champ.) ; costal are mostly biseriate, triseriate in widest part, the areolæ hyaline; subcostal area broad, triseriate in widest part. Body beneath black.

Length, $2.40 \mathrm{~mm}$.; width, $1.10 \mathrm{~mm}$.

Holotype, male, Barro Colorado Island, Canal Zone, Panama, Feb. 8, 1939, C. J. Drake.

The oblique fascia of the elytra and the small size separate this species from other members of the genus. The interrupted rostral channel separates it from Leptopharsa lineata Champion. 
Leptopharsa zeteki sp. nov.

Small, narrow. Head black, the frontal spines short and black. Antennæ moderately long, slender; segments I and II both short, black, the former about twice as long as the latter; III a little more than twice as long as IV, testaceous; IV slightly enlarged, embrowned towards the tip. Rostrum brown, black at apex, extending beyond middle of mesosternum. Rostral channel wide, wider and chordate on metasternum. Legs slender, testaceous, the tarsi brownish. Body beneath black.

Pronotum convex, finely pitted, black, testaceous behind; carinæ foliaceous, uniseriate, testaceous, some of the veinlets dark, the areolæ small; lateral carinæ slightly concave within in front, not so widely separated and subparallel behind. Paranota rather narrow, biseriate, testaceous, slightly wider in front, moderately reflexed. Hood small, testaceous, faintly produced forward in front. Elytra moderately constricted beyond the middle, strongly overlapping and jointly rounded behind; costal area moderately wide, testaceous, biseriate, the inner row of areolæ along the basal half of costal area smaller, the areolæ hyaline; subcostal area broad, triseriate, the veinlets opposite discoidal area black; sutural area elongate, impressed, the nervelets somewhat embrowned, three areolæ deep in widest part; sutural area becoming dark fuscous posteriorly, with three large, hyaline areolae near the apex.

Length, $2.00 \mathrm{~mm}$. ; width, $.80 \mathrm{~mm}$.

Holotype (male), allotype (female) and one paratype, Barro Colorado Island, Canal Zone, Panama, Feb. 1939. Three paratypes, near Colon, Canal Zone.

The short basal segment of antennæ and color separate this insect from other small species of the genus. This species (also G. paula n. sp.) was collected near the Barro Colorado Island Biological Laboratory, Gatun Lake, Institute for Research in Tropical America, Panama Canal, and is named in honor of the Director, Mr. James Zetek, who has taken a very active interest in the insect fauna of tropical America. 

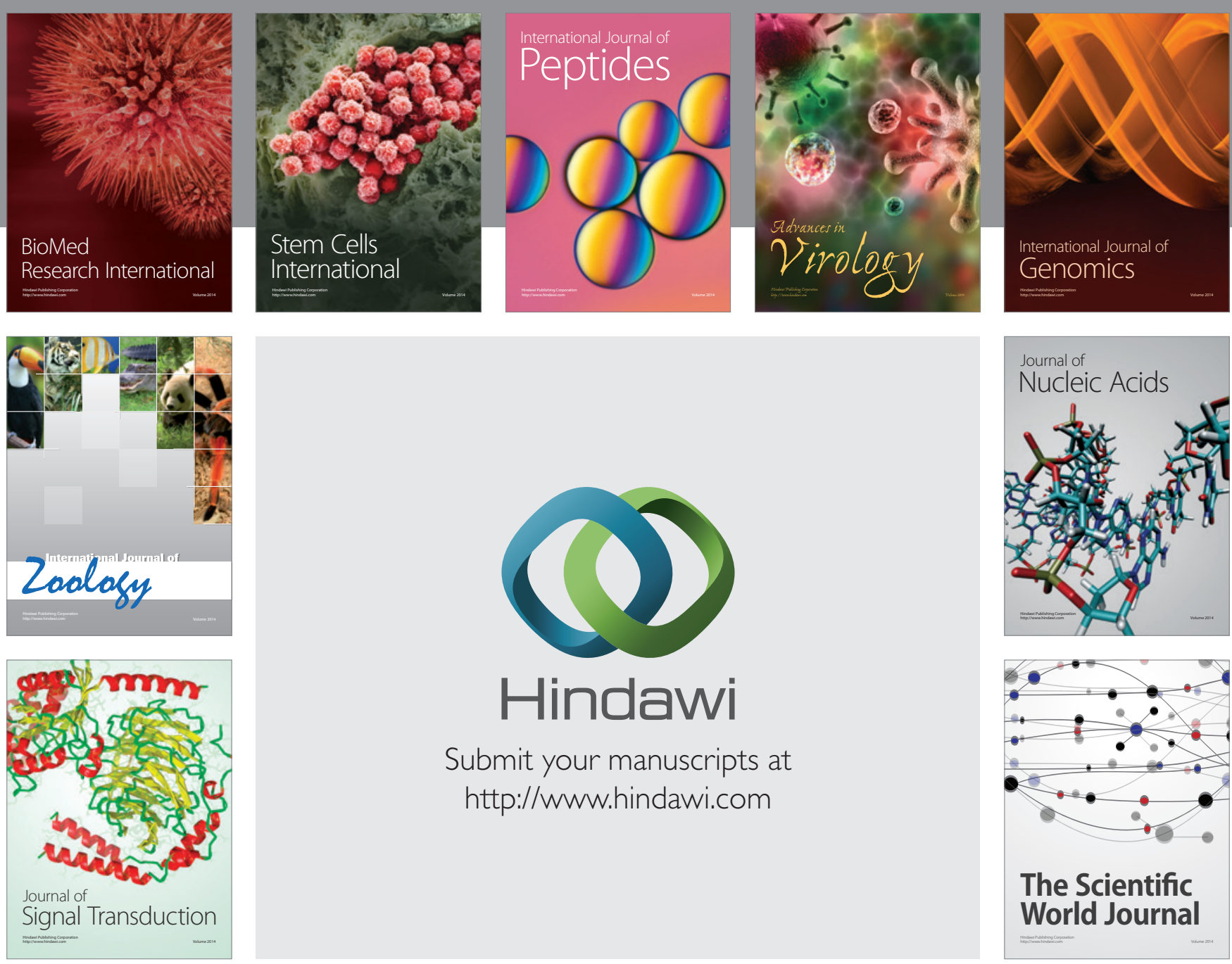

Submit your manuscripts at

http://www.hindawi.com
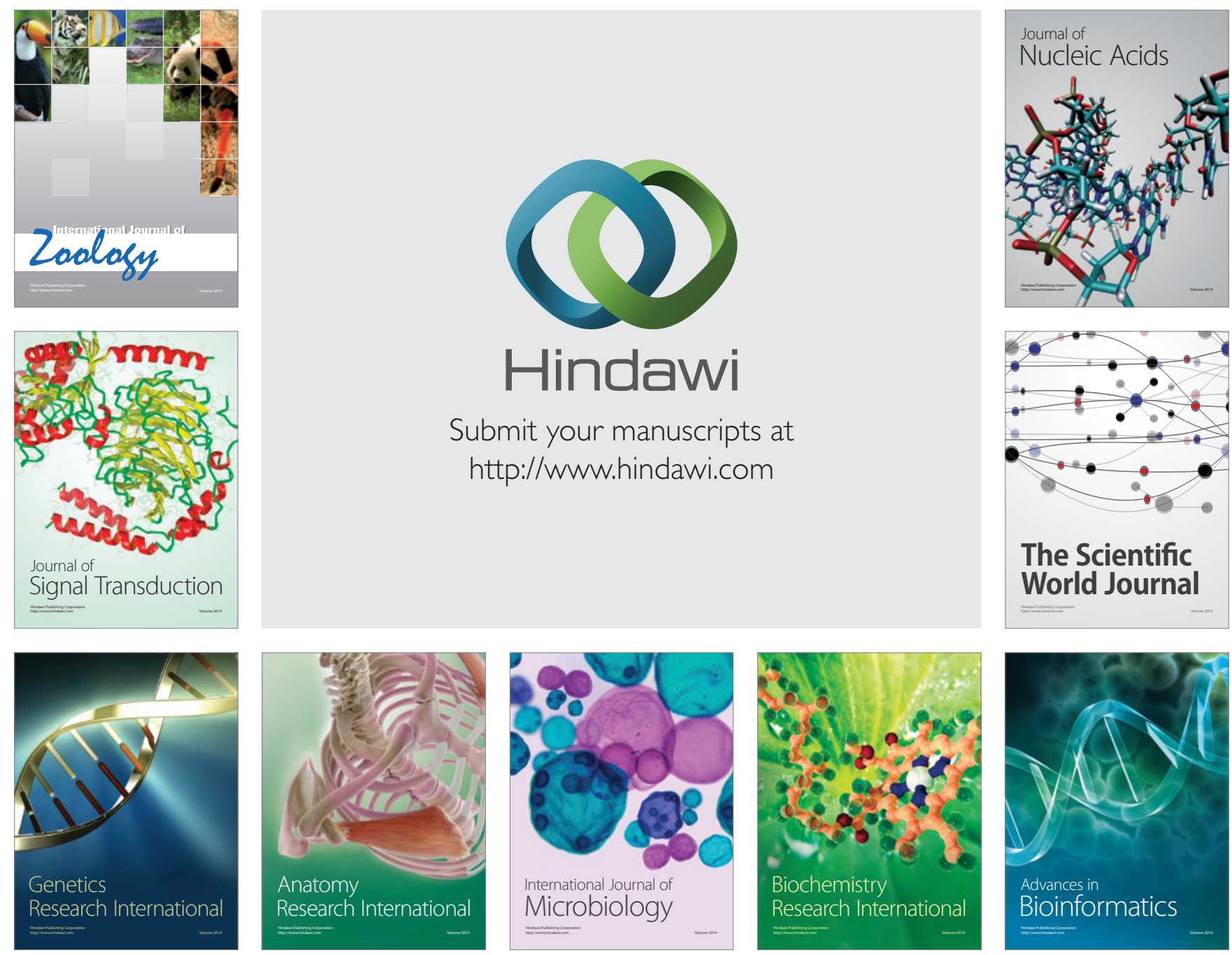

The Scientific World Journal
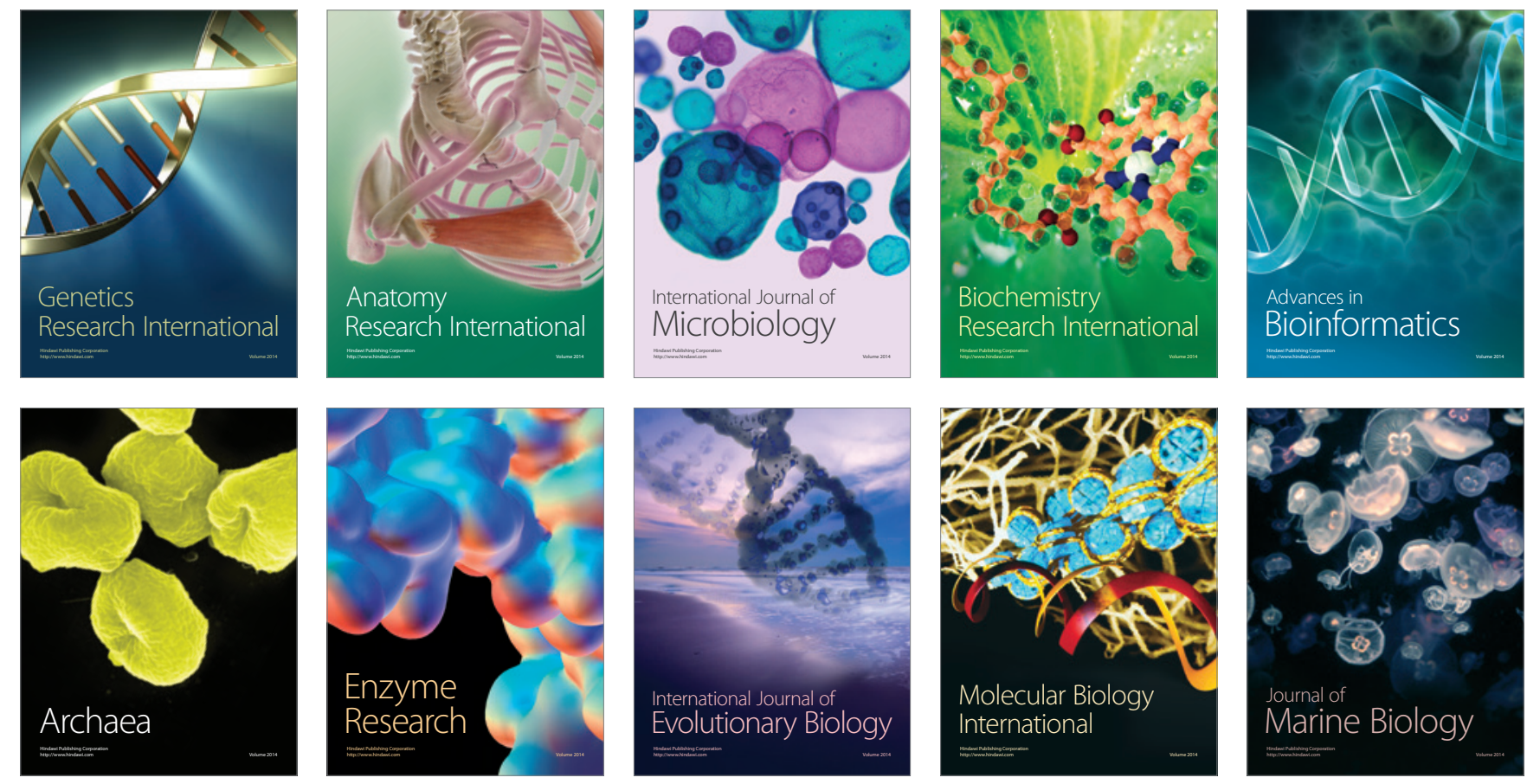